\title{
Vertical Profiles and Temporal Variations of Greenhouse Gases in the Stratosphere over Syowa Station, Antarctica
}

\author{
Daisuke Goto $^{1,2}$, Shinji Morimoto ${ }^{3}$, Shuji Aoki $^{3}$, Satoshi Sugawara ${ }^{4}$, Shigeyuki Ishidoya ${ }^{5}$, Yoichi Inai ${ }^{3}$, \\ Sakae Toyoda ${ }^{6}$, Hideyuki Honda ${ }^{7}$, Gen Hashida ${ }^{1}$, Takashi Yamanouchi ${ }^{1}$, and Takakiyo Nakazawa ${ }^{3}$ \\ ${ }^{1}$ National Institute of Polar Research (NIPR), Tachikawa, Japan \\ ${ }^{2}$ Department of Polar Science, The Graduate University for Advanced Studies (SOKENDAI), Tachikawa, Japan \\ ${ }^{3}$ Center for Atmospheric and Oceanic Studies, Tohoku University, Sendai, Japan \\ ${ }^{4}$ Miyagi University of Education, Sendai, Japan \\ ${ }^{5}$ National Institute of Advanced Industrial Science and Technology (AIST), Tsukuba, Japan \\ ${ }^{6}$ Department of Chemical Science and Engineering, School of Materials and Chemical Technology, \\ Tokyo Institute of Technology, Yokohama, Japan \\ ${ }^{7}$ Institute of Space and Astronautical Science (ISAS), Japan Aerospace Exploration Agency (JAXA), \\ Sagamihara, Japan
}

\begin{abstract}
Stratospheric air sampling using balloon-borne cryogenic air samplers was conducted over Syowa Station, Antarctica in four austral summers between 1998 and 2013. The $\mathrm{CH}_{4}$ and $\mathrm{N}_{2} \mathrm{O}$ mole fractions decreased with increasing altitude due to chemical reactions and photodissociation in the stratosphere, and a compact positive correlation between $\mathrm{CH}_{4}$ and $\mathrm{N}_{2} \mathrm{O}$ was found in their vertical profiles. The vertical profiles of $\mathrm{CO}_{2}$ and $\mathrm{SF}_{6}$ mole fractions showed high values in the lower stratosphere, decreasing gradually with altitude, and then becoming almost constant at altitudes above $18 \mathrm{~km}$. Stratospheric $\mathrm{CO}_{2}$ and $\mathrm{SF}_{6}$ above $18 \mathrm{~km}$ over Antarctica increased secularly at the respective average rates of 1.82

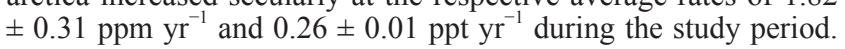
The $\mathrm{CO}_{2}$ and $\mathrm{SF}_{6}$ mole fractions increased in the Antarctic stratosphere, but were delayed $4.5 \pm 0.5$ and $5.6 \pm 0.2$ years, respectively, compared to the tropical troposphere. The secular increase in stratospheric $\mathrm{CH}_{4}$ was also detected by classifying the measured mole fractions in terms of the $\mathrm{N}_{2} \mathrm{O}$ depletion in the stratosphere.
\end{abstract}

(Citation: Goto, D., S. Morimoto, S. Aoki, S. Sugawara, S. Ishidoya, Y. Inai, S. Toyoda, H. Honda, G. Hashida, T. Yamanouchi, and T. Nakazawa, 2017: Vertical profiles and temporal variations of greenhouse gases in the stratosphere over Syowa Station, Antarctica. SOLA, 13, 224-229, doi:10.2151/sola.2017041.)

\section{Introduction}

Atmospheric greenhouse gases, such as $\mathrm{CO}_{2}, \mathrm{CH}_{4}$, and $\mathrm{N}_{2} \mathrm{O}$, have significantly increased since the late 18 -century. To address global climate change due to human activities, it is crucial to identify spatio-temporal variations in greenhouse gases in the atmosphere. For that purpose, a number of observations have been conducted. However, only a few research groups have been devoted to observations in the stratosphere using scientific balloons, aircraft, and satellites (e.g., Bischof et al. 1985; Schmidt and Khedim 1991; Nakazawa et al. 1995; Engel et al. 2017; Rosenlof 2002; Foucher et al. 2011). Therefore, our knowledge of variations in stratospheric greenhouse gases remains insufficient. In particular, their behavior in the Antarctic stratosphere is not yet well understood, because long-term observations of related gases have been primarily conducted at northern middle latitudes (e.g., Schmidt and Khedim 1991; Nakazawa et al. 2002; Aoki et al. 2003; Engel

Corresponding author: Daisuke Goto, National Institute of Polar Research, 10-3 Midori-cho, Tachikawa 190-8518, Japan. E-mail: goto.daisuke@nipr. ac.jp. (C)2017, the Meteorological Society of Japan. et al. 2009).

To elucidate vertical distributions and temporal variations in greenhouse gases in the Antarctic stratosphere, we collected air samples using large balloon-borne cryogenic air samplers over the Japanese Antarctic station, Syowa $\left(69.00^{\circ} \mathrm{S}, 39.58^{\circ} \mathrm{E}\right)$, in the austral summers in 1997/98 and 2003/04. Subsequently, we also collected stratospheric air using newly developed compact cryogenic air samplers over Syowa in the austral summers in 2007/08 and $2012 / 13$.

In this study, we present all measured values of $\mathrm{CO}_{2}, \mathrm{SF}_{6}$, $\mathrm{CH}_{4}$, and $\mathrm{N}_{2} \mathrm{O}$ mole fractions obtained from these observations as their first long-term records in the Antarctic stratosphere and discuss their stratospheric vertical profiles over Antarctica. The secular trends in stratospheric $\mathrm{CO}_{2}, \mathrm{SF}_{6}$, and $\mathrm{CH}_{4}$ mole fractions are also discussed.

\section{Method}

Air samples were collected from the stratosphere over Syowa using two types of samplers; the first was a cryogenic air sampler with liquid helium as a coolant (Honda et al. 1996), hereafter referred to as the cryo-sampler; the other was a compact cryogenic air sampler equipped with a Joule-Thomson mini cooler (Morimoto et al. 2009), hereafter referred to as the JT-sampler. Stratospheric air was collected using the cryo-sampler on 3 January 1998, 26 December 2003, and 5 January 2004 (Sugawara et al. 2010). The JT-sampler was used to collect stratospheric air on 4 January 2008, 31 December 2012, and 10 January 2013. The air sampling procedures using the two samplers are described in detail in Nakazawa et al. (1995) and Morimoto et al. (2009). By performing the air storage tests over 1-3 months for each sampler, the measured $\mathrm{CO}_{2}$ mole fraction values of the air collected in the JT-sampler were corrected by $0.0-1.0 \mathrm{ppm}$, while no correction was applied to those in the cryo-sampler. Each air sampler was launched using a scientific plastic balloon, and landed on the sea ice using a parachute after collecting the stratospheric air at assigned altitudes between 10 and $30 \mathrm{~km}$. The dates and altitudes of air sampling are summarized in Table 1. The samples obtained in 2003 showed anomalous mole fraction values of $\mathrm{CO}_{2}$ for an unknown reason, and we failed to collect high quality samples at 22.3, 24.7, 27.3 $\mathrm{km}$ on 31 December 2012 and $19.6 \mathrm{~km}$ on 10 January 2013 due to technical issues. Therefore, data from these altitudes and dates were not used for this study.

The air samples collected were analyzed at Tohoku University for the mole fractions of $\mathrm{CO}_{2}, \mathrm{CH}_{4}, \mathrm{~N}_{2} \mathrm{O}$, and $\mathrm{SF}_{6}$ in 3-5 months after air sampling. The analyzers, analytical precision, and calibration scales for measurements of the respective components are summarized in Table 2 . 
Table 1. Summary of dates and altitudes of stratospheric air sampling conducted over Syowa Station. Air samples at underlined altitudes were not used in this study (cf. text).

\begin{tabular}{lllllllll}
\hline \multicolumn{1}{c}{ Date } & \multicolumn{10}{c}{ Altitude (km) } \\
\hline January 3, 1998 & 10.4 & 12.4 & 14.3 & 16.7 & 18.5 & 20.4 & 22.7 \\
& 25.1 & 26.9 & 28.9 & 29.8 & & & \\
December 26, 2003 & $\underline{10.3}$ & $\underline{12.3}$ & $\underline{\underline{14.4}}$ & $\underline{16.4}$ & $\underline{18.4}$ & $\underline{20.5}$ & $\underline{22.7}$ \\
& 10.2 & 12.2 & $\underline{28.4}$ & $\underline{29.5}$ & & & \\
January 5, 2004 & 24.8 & 26.6 & 28.5 & 29.4 & 18.5 & 20.3 & 22.7 \\
January 4, 2008 & 18.0 & 25.0 & & & & & \\
December 31, 2012 & $\underline{22.3}$ & $\underline{\underline{24.7}}$ & $\underline{27.3}$ & 28.5 & & & \\
January 10, 2013 & 14.6 & $\underline{19.6}$ & 22.2 & 27.2 & & & \\
\hline
\end{tabular}

Table 2. Analyzers, analytical precision and calibration scales for measurements of the respective components in this study.

\begin{tabular}{clcc}
\hline Components & \multicolumn{1}{c}{ Analyzer } & Precision & Scale* \\
\hline $\mathrm{CO}_{2}$ & $\begin{array}{l}\text { NDIR (Horiba VIA-500R or } \\
\text { LI-COR LI-6262) }\end{array}$ & $<0.05 \mathrm{ppm}$ & TU-2010 \\
& GC/FID (Shimadzu GC-9A or & $<1.5 \mathrm{ppb}$ & TU-1987 \\
$\mathrm{CH}_{4}$ & Agilent 6890) & $<0.3 \mathrm{ppb}$ & TU-2006 \\
& & $<0.2 \mathrm{ppt}$ & TU-2002 \\
$\mathrm{N}_{2} \mathrm{O}$ & GC/ECD (Agilent 6890) & & \\
$\mathrm{SF}_{6}$ & &
\end{tabular}

NDIR: Non-dispersive infrared analyzer, GC: Gas chromatograph, FID: Flame ionization detector, ECD: Electron capture detector, *Gravimetrically prepared

\section{Results and discussion}

Figures $1 \mathrm{a}$ and $1 \mathrm{~b}$ show vertical profiles of $\mathrm{CH}_{4}$ and $\mathrm{N}_{2} \mathrm{O}$ mole fractions in the stratosphere over Syowa obtained in 1998 and 2004 using the cryo-sampler and in 2008 and 2012/13 using the JT-sampler. Daily mean $\mathrm{CH}_{4}$ mole fraction observed at Syowa (Aoki et al. 1992) on the day each profile was obtained, as well as the $\mathrm{N}_{2} \mathrm{O}$ and $\mathrm{SF}_{6}$ mole fractions measured using a grab sampling method at the station on the date close to the day of stratospheric air sampling, are plotted in the figure with reference to the surface values. $\mathrm{CH}_{4}$ is destroyed by chemical reactions with $\mathrm{OH}, \mathrm{O}\left({ }^{1} \mathrm{D}\right)$ and $\mathrm{Cl}$, and $\mathrm{N}_{2} \mathrm{O}$ by photodissociation and reactions with $\mathrm{O}\left({ }^{1} \mathrm{D}\right)$ in the stratosphere (e.g., Nakazawa et al. 2002). As shown in Figs. 1a and $1 \mathrm{~b}$, both $\mathrm{CH}_{4}$ and $\mathrm{N}_{2} \mathrm{O}$ mole fractions decrease with increasing altitude, as expected. The mean rates of decrease in the $\mathrm{CH}_{4}$ profiles for $1998(10.4-29.8 \mathrm{~km}), 2004(10.2-29.4 \mathrm{~km})$, and $2012 / 13(14.6-28.5 \mathrm{~km})$, defined as a slope of linear lines fitted to each profile, were calculated as $38.6 \pm 4.0,38.0 \pm 2.7$, and $36.8 \pm$ $11.3 \mathrm{ppb} \mathrm{km}{ }^{-1}$, respectively. These rates are in good agreement with each other within the estimated uncertainties. The corresponding rates of decrease in the $\mathrm{N}_{2} \mathrm{O}$ profiles were calculated as $11.4 \pm 0.8,10.4 \pm 0.6$, and $9.8 \pm 3.1 \mathrm{ppb} \mathrm{km}^{-1}$, which are also close to each other. The slopes for the 2008 profiles were not calculated because there were only two data points.

Sugawara et al. (1997) also observed a similar $\mathrm{CH}_{4}$ profile in the stratosphere over the northern part of Japan using the cryosampler. Their measured $\mathrm{CH}_{4}$ mole fraction values decreased rapidly from 14 to $34.7 \mathrm{~km}$ with a rate of about $38 \mathrm{ppb} \mathrm{km}^{-1}$. Vertical $\mathrm{N}_{2} \mathrm{O}$ profiles similar to our result were obtained in the stratosphere over India, France, Sweden (Harnisch et al. 1998) and Japan (Toyoda et al. 2004), but their rates of decrease are about 12$20 \mathrm{ppb} \mathrm{km}{ }^{-1}$, which are slightly larger than the values over Syowa.
Fig. 1. Vertical profiles of a) $\mathrm{CH}_{4}$, b) $\mathrm{N}_{2} \mathrm{O}$, c) $\mathrm{CO}_{2}$, and d) $\mathrm{SF}_{6}$ mole fractions over Syowa Station in 1998, 2004, 2008, and 2012/2013. Also plotted are the $\mathrm{CH}_{4}$ and $\mathrm{CO}_{2}$ mole fractions observed at the Station on the same day as stratospheric air sampling (crosses) and the $\mathrm{N}_{2} \mathrm{O}$ and $\mathrm{SF}_{6}$ mole fractions observed at the Station on the date close to the day of stratospheric air sampling (open circles).
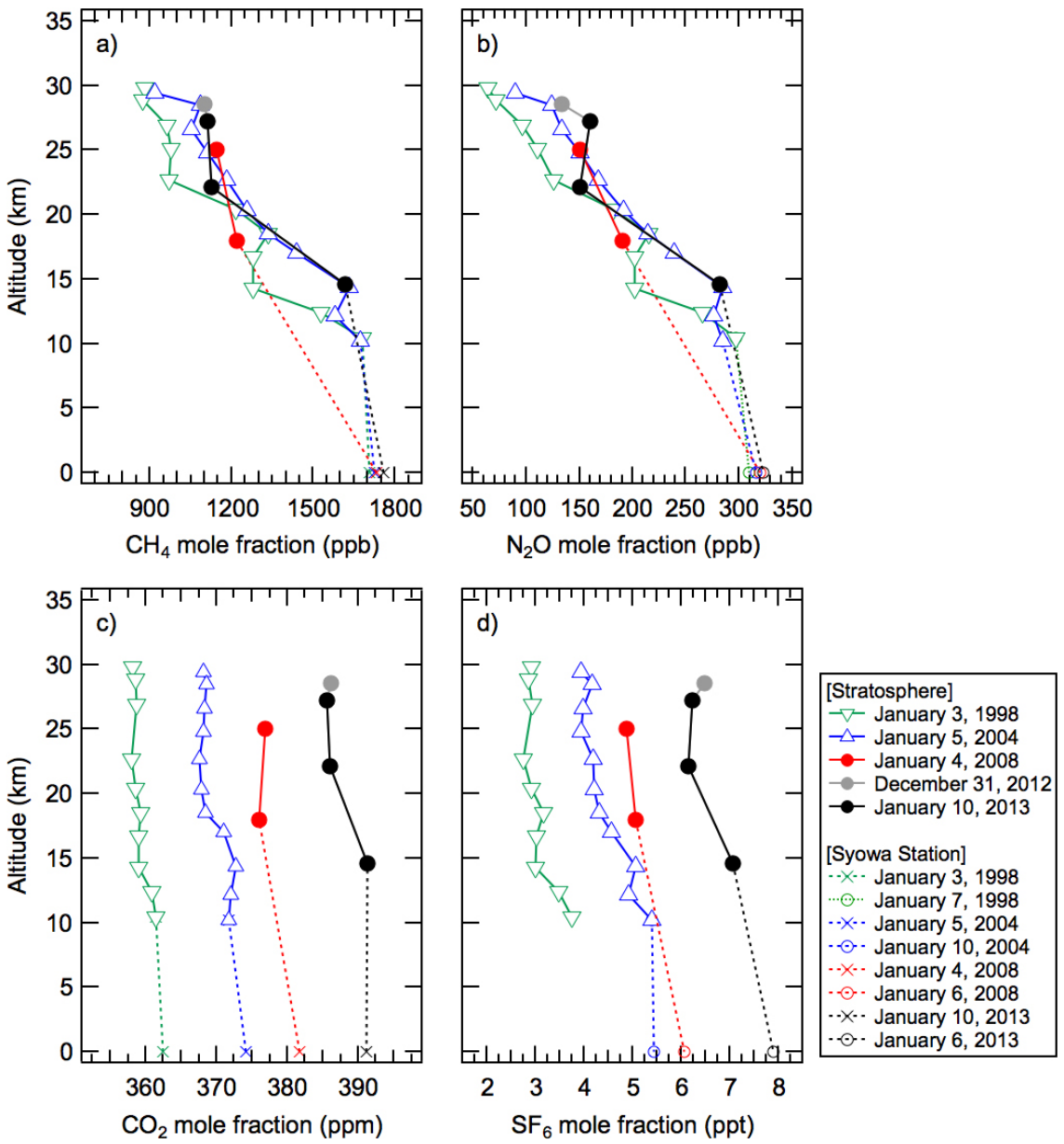
It is seen from Fig. 2 that the $\mathrm{CH}_{4}$ and $\mathrm{N}_{2} \mathrm{O}$ mole fractions observed over Syowa are positively correlated well with each other. Such a compact correlation was also reported by Michelsen et al. (1998) by examining the mole fractions of $\mathrm{CH}_{4}$ and $\mathrm{N}_{2} \mathrm{O}$ over a wide range of altitudes and latitudes, as well as by Nakazawa et al. (2002) from their measurements of the two variables over Japan, Scandinavia and Antarctica.

Figures $1 \mathrm{c}$ and $1 \mathrm{~d}$ show vertical profiles of $\mathrm{CO}_{2}$ and $\mathrm{SF}_{6}$ mole fractions observed in the stratosphere over Syowa in 1998, 2004, 2008 , and 2012/13. As shown in the figure, the $\mathrm{CO}_{2}$ and $\mathrm{SF}_{6}$ mole fractions decrease rapidly with altitude from 10 to $18 \mathrm{~km}$ and then show almost constant values. The rates of decrease in $\mathrm{CO}_{2}$ $\left(\mathrm{SF}_{6}\right)$ above $18 \mathrm{~km}$ are calculated to be $0.05 \pm 0.04$ and $-0.02 \pm$ $0.03 \mathrm{ppm} \mathrm{km}{ }^{-1}\left(0.01 \pm 0.01\right.$ and $\left.0.03 \pm 0.01 \mathrm{ppt} \mathrm{km}{ }^{-1}\right)$ for 1998 and 2004, respectively, and the corresponding rates below $18 \mathrm{~km}$ are $0.43 \pm 0.14$ and $0.35 \pm 0.20 \mathrm{ppm} \mathrm{km}^{-1}(0.12 \pm 0.04$ and 0.10 $\left.\pm 0.04 \mathrm{ppt} \mathrm{km}{ }^{-1}\right)$. In the stratosphere, there are no $\mathrm{SF}_{6}$ sources and sinks. Although oxidizing $\mathrm{CH}_{4}$ in the stratosphere produces $\mathrm{CO}_{2}$, its contribution to stratospheric $\mathrm{CO}_{2}$ mole fraction is $0.8 \mathrm{ppm}$ at most, even if the observed vertical $\mathrm{CH}_{4}$ profiles, decreased from about $1700 \mathrm{ppb}$ at $10 \mathrm{~km}$ to about $900 \mathrm{ppb}$ at $30 \mathrm{~km}$, were formed only by the oxidation of stratospheric $\mathrm{CH}_{4}$. Therefore, the steep gradients of $\mathrm{CO}_{2}$ and $\mathrm{SF}_{6}$ profiles below $18 \mathrm{~km}$ would be primarily influenced by transportation of tropospheric air with high mole fractions.

Similar $\mathrm{CO}_{2}$ and $\mathrm{SF}_{6}$ profiles were obtained over the Arctic, France, and India using a balloon-borne cryogenic air sampler from 1987 to 1995 (Harnish et al. 1998; Strunk et al. 2000). Aoki et al. (2003) and Engel et al. (2009) also observed similar $\mathrm{CO}_{2}$ profiles at northern mid-latitudes. However, their results showed that the difference in $\mathrm{CO}_{2}$ mole fraction between the middle and lower stratosphere was about $7-8 \mathrm{ppm}$, which is twice as large as our finding obtained in the Antarctic stratosphere. Such a latitude-dependent vertical $\mathrm{CO}_{2}$ difference could be mainly related with the effects (1) that the mole fraction of upper tropospheric $\mathrm{CO}_{2}$ is higher in the northern hemisphere than in the southern hemisphere on average (Matsueda et al. 2015) and the tropospheric and stratospheric air exchange occurs through various processes, such as blockings, cut-off cyclones, and tropopause folds (e.g., Holton et al. 1995), and (2) that the tropospheric air with high $\mathrm{CO}_{2}$ mole fractions, intruded into the stratosphere in the tropics, has a stronger influence on lower stratospheric $\mathrm{CO}_{2}$ in northern midlatitudes than in Antarctica, since its poleward transport through the lower stratosphere is faster in the northern hemisphere than in the southern hemisphere (Flury et al. 2013).

In addition, Figs. 1c and $1 \mathrm{~d}$ also show that the stratospheric

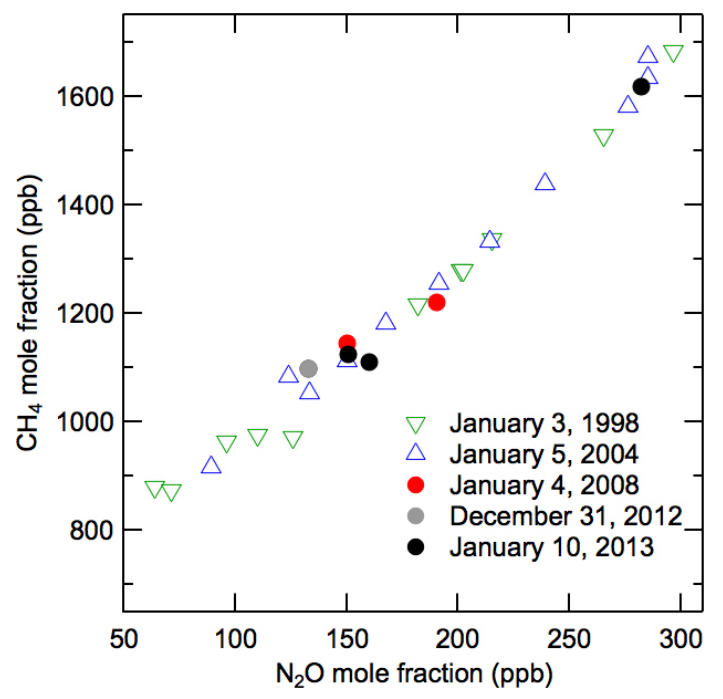

Fig. 2. Correlation plots of $\mathrm{CH}_{4}$ and $\mathrm{N}_{2} \mathrm{O}$ mole fractions observed in the stratosphere over Syowa Station.
$\mathrm{CO}_{2}$ and $\mathrm{SF}_{6}$ mole fractions increase with time. To examine such increasing trends, the mole fractions of $\mathrm{CO}_{2}$ and $\mathrm{SF}_{6}$ measured above $18 \mathrm{~km}$, where values become almost constant, were simply averaged and plotted in Fig. 3. The long-term trend derived by applying a digital filtering technique (Nakazawa et al. 1997) to the $\mathrm{CO}_{2}$ record obtained from continuous measurements at Syowa (Morimoto et al. 2003) is also shown in Fig. 3a. We also measured the $\mathrm{SF}_{6}$ mole fraction at the station based on weekly air sampling (our unpublished data); the long-term trend for the 2004-2013 period obtained using the digital filtering technique is shown in Fig. 3b. As shown in Figs. 3a and 3b, the stratospheric $\mathrm{CO}_{2}$ and $\mathrm{SF}_{6}$ increased secularly with a few years of delay, compared to their increasing trends at Syowa. The average rates of increase in stratospheric $\mathrm{CO}_{2}$ and $\mathrm{SF}_{6}$ for the 1998-2013 period were calculated from our observational results as $1.82 \pm 0.31 \mathrm{ppm} \mathrm{yr}^{-1}$ and 0.22 $\pm 0.01 \mathrm{ppt} \mathrm{yr}^{-1}$, respectively. The rate of increase in stratospheric $\mathrm{CO}_{2}$ is in good agreement with the result at Syowa (1.88 $\left.\mathrm{ppm} \mathrm{yr}^{-1}\right)$ for the same period. Aoki et al. (2003) reported from their balloon observations over Japan for the 1985-2000 period that stratospheric $\mathrm{CO}_{2}$ increased at $1.4 \mathrm{ppm} \mathrm{yr}^{-1}$, which is close to the value obtained from their aircraft observations in the upper troposphere over Japan for the same period. The discrepancy between the rates of increase in $\mathrm{CO}_{2}$ reported by Aoki et al. (2003) and this study is probably ascribed to the different observation periods, since the $\mathrm{CO}_{2}$ growth rate increased secularly for the period covered by the two observations (e.g., GLOBALVIEW- $\mathrm{CO}_{2}, 2013$ ).

The observed $\mathrm{SF}_{6}$ mole fraction data at Syowa yielded an

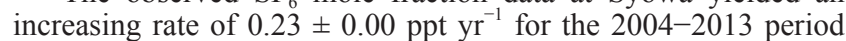
(our unpublished data), which is in agreement with the value derived for stratospheric $\mathrm{SF}_{6}$. The $\mathrm{SF}_{6}$ mole fractions over Antarctica were also observed using MIPAS (Michelson Interferometer for

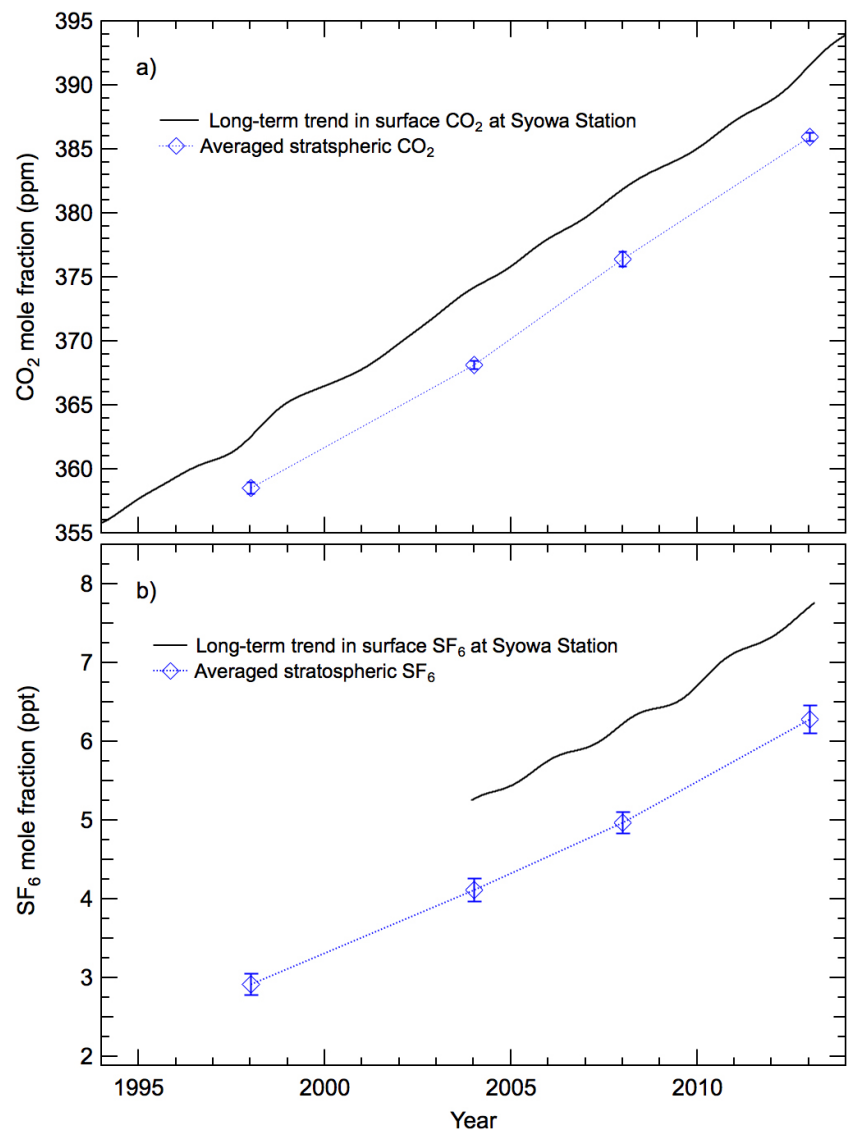

Fig. 3. Mean a) $\mathrm{CO}_{2}$ and b) $\mathrm{SF}_{6}$ mole fraction values $>18 \mathrm{~km}$ over Syowa Station (blue diamonds). Error bars indicate one standard deviation in the respective values. Long-term trends in $\mathrm{CO}_{2}$ and $\mathrm{SF}_{6}$ observed at Syowa Station (black lines) are also plotted. 
Passive Atmospheric Sounding) aboard ENVISAT (Environmental Satellite) (Haenel et al. 2015). By analyzing the MIPAS monthly zonal mean data at $67.5^{\circ} \mathrm{S}$ in January of 2002-2012, we estimated the rate of increase in $\mathrm{SF}_{6}$ at $25 \mathrm{~km}$ to be $0.19 \pm 0.04 \mathrm{ppt} \mathrm{yr}^{-1}$. The estimated rate is slightly lower than our tropospheric and stratospheric values on average, but both results are in agreement with each other in a margin of uncertainty. Our data obtained for the Antarctic stratosphere will be indispensable for validating satellite-based $\mathrm{SF}_{6}$ observations.

Because there are no strong $\mathrm{CO}_{2}$ and $\mathrm{SF}_{6}$ sources in the stratosphere, increases in stratospheric $\mathrm{CO}_{2}$ and $\mathrm{SF}_{6}$ are mainly attributable to an intrusion of tropospheric air into the stratosphere. In general, tropospheric air enters the stratosphere in the tropics, and then moves toward middle and high latitudes over a few or several years. This circulation is well known as the Brewer-Dobson circulation. Due to this circulation, the tropospheric mole fraction levels of $\mathrm{CO}_{2}$ and $\mathrm{SF}_{6}$ are observed in the stratosphere with some years of delay (e.g., Waugh and Hall 2002). We calculated approximate lag times of $\mathrm{CO}_{2}$ and $\mathrm{SF}_{6}$ between the troposphere and stratosphere. In this calculation, the averages of $\mathrm{CO}_{2}$ and $\mathrm{SF}_{6}$ mole fractions above $18 \mathrm{~km}$ over Syowa were compared with the respective secular trends observed at Mauna Loa $\left(19.54^{\circ} \mathrm{N}\right.$, $155.58^{\circ} \mathrm{W}, 3397 \mathrm{~m}$ above sea level), Hawaii by the NOAA/ESRL GMD (Dlugokencky et al. 2017) since 1969 and the NOAA/ESRL halocarbons in situ program (e.g., Rigby et al. 2010) since 2000. Prior to comparison, $0.2 \mathrm{ppm}$ was added to the $\mathrm{NOAA} \mathrm{CO}_{2}$ data to adjust the NOAA scale (WMO-X2007) to our scale (TU-2010). Since we confirmed that our $\mathrm{SF}_{6}$ scale (TU-2002) is consistent with the NOAA scale (WMO-2014) within \pm 0.07 ppt, no correction was applied to the $\mathrm{SF}_{6}$ data. The resultant lag times of $\mathrm{CO}_{2}$ were $3.8,5.1,4.5$, and 4.7 years for the 1998, 2004, 2008, and 2012/2013 observations, respectively, with a mean of $4.5 \pm$ 0.5 years. The respective $\mathrm{SF}_{6}$ lag times calculated for 2008 and 2012/2013 observations were 5.7 and 5.4 years, and their $5.6 \pm$ 0.2 year average was about one year larger than that of $\mathrm{CO}_{2}$. These results indicate that the stratospheric air over Syowa was older by about 4-6 years than the tropical tropospheric air. The difference in the estimated time lag between $\mathrm{CO}_{2}$ and $\mathrm{SF}_{6}$ was also reported by previous studies (e.g., Andrew et al. 2001; Sugawara et al. 2017), however, the cause is not yet understood well. The downward transport of the mesospheric air with low $\mathrm{SF}_{6}$ mole fractions is suggested as one of possible candidates (e.g., Reddmann et al. 2001; Linz et al. 2017).

An increase in tropospheric $\mathrm{CH}_{4}$ has been observed at various places worldwide, but such a trend is not clearly observable in our stratospheric $\mathrm{CH}_{4}$ mole fractions provided in Fig. 1. To examine

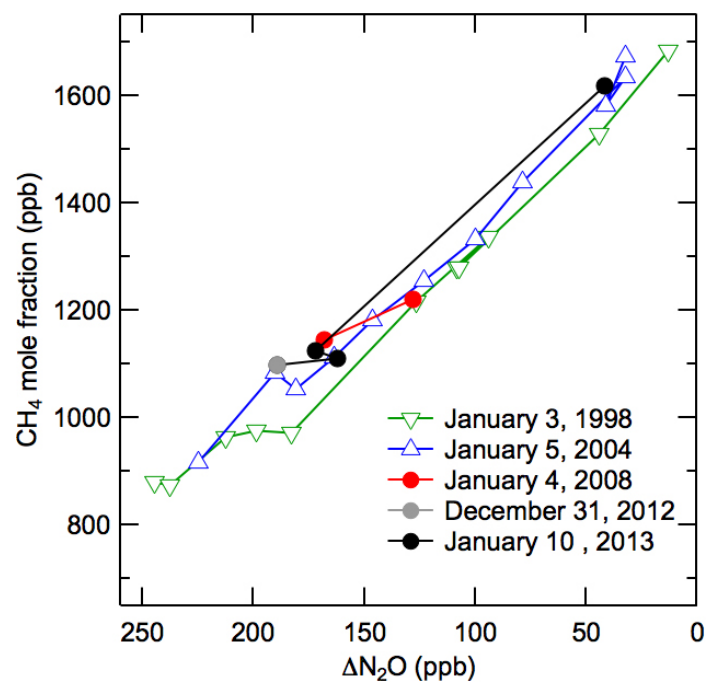

Fig. 4. Correlation plots of $\mathrm{CH}_{4}$ and $\Delta \mathrm{N}_{2} \mathrm{O}$ observed in the stratosphere over Syowa Station (cf. text). the secular trend in $\mathrm{CH}_{4}$ in the Antarctic stratosphere, we analyzed our $\mathrm{CH}_{4}$ and $\mathrm{N}_{2} \mathrm{O}$ mole fraction data using a method similar to Rohs et al. (2006). In this analysis, we first calculated the depletion in the $\mathrm{N}_{2} \mathrm{O}$ mole fraction $\left(\Delta \mathrm{N}_{2} \mathrm{O}\right)$ that occurred during its transportation from the troposphere to stratosphere over Syowa using the following equation:

$$
\Delta \mathrm{N}_{2} \mathrm{O}=C_{t r p}\left(t-T_{a}\right)-C(t) .
$$

Here, $C(t)$ is the $\mathrm{N}_{2} \mathrm{O}$ mole fraction observed in the stratosphere over Syowa at time $t, T_{a}$ is the age of stratospheric air for the observed $C(t)$, and $C_{t r p}\left(t-T_{a}\right)$ is the tropospheric $\mathrm{N}_{2} \mathrm{O}$ mole fraction at time $t-T_{a}$. In this calculation, the $\mathrm{N}_{2} \mathrm{O}$ mole fraction data at Mauna Loa, from the NOAA/ESRL halocarbons in situ program, were used for $C_{t r p}$, and the $\mathrm{CO}_{2}$ lag times were used for $T_{a}$, to exclude possible influence by the mesospheric air. The measured values of $\mathrm{CH}_{4}$ mole fraction are plotted in Fig. 4 against $\Delta \mathrm{N}_{2} \mathrm{O}$. As shown in the figure, the relationship between $\Delta \mathrm{N}_{2} \mathrm{O}$ and $\mathrm{CH}_{4}$ for each year is almost linear, and the line shifts upward year by year. This implies that the secular $\mathrm{CH}_{4}$ increase can be detected by classifying the measured values of $\mathrm{CH}_{4}$ mole fraction in terms of $\Delta \mathrm{N}_{2} \mathrm{O}$. Then, the average $\mathrm{CH}_{4}$ mole fractions for four ranges of $\Delta \mathrm{N}_{2} \mathrm{O}$, i.e., $50-100,100-150,125-175$, and $150-200 \mathrm{ppb}$, were calculated from a linear line fit to the $\Delta \mathrm{N}_{2} \mathrm{O}-\mathrm{CH}_{4}$ correlation plots for each observation. The obtained average values are plotted in Fig. 5 against year, together with long-term trend and best-fit curve of the $\mathrm{CH}_{4}$ mole fraction data at Syowa (Aoki et al. 1992). It should be noted that the stratospheric $\mathrm{CH}_{4}$ mole fractions are shifted back by $T_{a}$ in Fig. 5 to directly compare their temporal changes with those at Syowa.

In Fig. 5, the stratospheric $\mathrm{CH}_{4}$ mole fraction over Syowa clearly increases for the 1998-2013 period. The rates of increase in the $\mathrm{CH}_{4}$ mole fraction were $4.2 \pm 0.1,4.8 \pm 0.1,4.5 \pm 0.4$, and

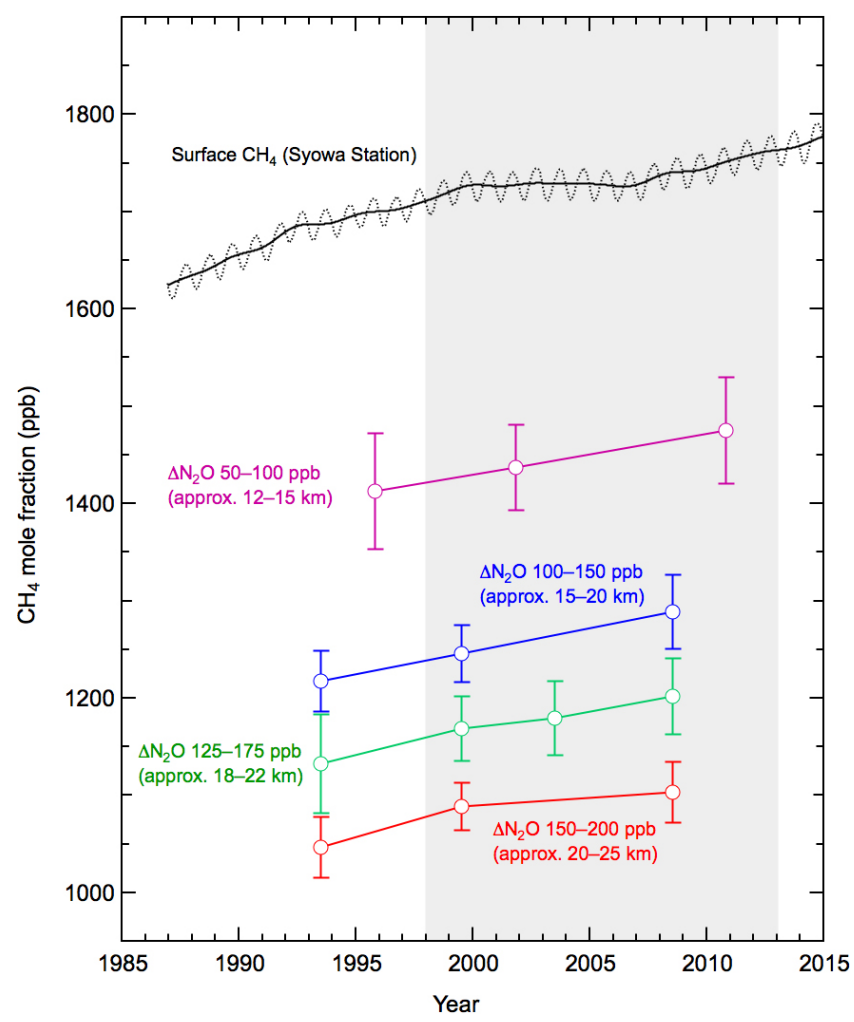

Fig. 5. Temporal changes in mean $\mathrm{CH}_{4}$ mole fractions for $\Delta \mathrm{N}_{2} \mathrm{O}$ ranges: 50-100 (purple), 100-150 (blue), 125-175 (green), and 150-200 (red) ppb. Long-term trend (black solid line) and best-fit curve (black dotted line) of the $\mathrm{CH}_{4}$ mole fraction data obtained at Syowa Station are also shown. It should be noted that the stratospheric $\mathrm{CH}_{4}$ mole fractions are shifted back by the lag time of stratospheric air $\left(T_{a}\right)$. Shaded area indicates the period of stratospheric observations over Syowa. 
$3.6 \pm 1.5 \mathrm{ppb} \mathrm{yr}^{-1}$ for the respective $\Delta \mathrm{N}_{2} \mathrm{O}$ ranges of $50-100,100-$ $150,125-175$, and $150-200 \mathrm{ppb}$. On the other hand, the $\mathrm{CH}_{4}$ data from Syowa yield $3.6 \pm 0.1 \mathrm{ppb} \mathrm{yr}^{-1}$ for the period of 1995.82010.8 and $3.9 \pm 0.1 \mathrm{ppb} \mathrm{yr}^{-1}$ for 1993.5-2008.5, which can be compared to the respective results for the $\Delta \mathrm{N}_{2} \mathrm{O}$ range of $50-$ $100 \mathrm{ppb}$ and the $\Delta \mathrm{N}_{2} \mathrm{O}$ ranges of $100-150,125-175$, and $150-$ $200 \mathrm{ppb}$. Although the rates of increase in stratospheric $\mathrm{CH}_{4}$ are slightly larger than the values at Syowa, the present analysis indicates that the secular increase in stratospheric $\mathrm{CH}_{4}$ can also be detected over Antarctica from the measured values using the $\mathrm{N}_{2} \mathrm{O}$ depletion during transport of air from the tropical troposphere to the Antarctic stratosphere. At Syowa, the $\mathrm{CH}_{4}$ mole fraction increased steadily in the 1980s and 1990s, stagnated around 2000, and then increased again from 2006. Such an irregular change in the $\mathrm{CH}_{4}$ mole fraction was observed globally (e.g., Dlugokencky et al. 2009). However, the $\mathrm{CH}_{4}$ stagnation is not clearly detectable in the stratosphere over Syowa at this stage, because the stratospheric $\mathrm{CH}_{4}$ data over Syowa is sparse.

\section{Summary}

To understand the vertical distributions and temporal variations in $\mathrm{CO}_{2}, \mathrm{CH}_{4}, \mathrm{~N}_{2} \mathrm{O}$, and $\mathrm{SF}_{6}$ in the Antarctic stratosphere, we collected air samples over Syowa station in the austral summers of 1997/98, 2003/04, 2007/08, and 2012/13 using balloon-borne cryogenic air samplers and JT-samplers. The samples were analyzed for mole fractions of the respective constituents at Tohoku University in 3-5 months after air sampling. The $\mathrm{CO}_{2}$ and $\mathrm{SF}_{6}$ mole fractions had high values in the lower stratosphere, decreased with altitude and became almost constant above $18 \mathrm{~km}$. By comparing the average mole fractions of $\mathrm{CO}_{2}$ and $\mathrm{SF}_{6}$ above $18 \mathrm{~km}$ over Syowa with tropospheric data from Mauna Loa, the lag time in secular increase was estimated as $4.5 \pm 0.5$ years for $\mathrm{CO}_{2}$ and 5.6 \pm 0.2 years for $\mathrm{SF}_{6}$. The $\mathrm{CH}_{4}$ and $\mathrm{N}_{2} \mathrm{O}$ mole fractions decreased with increasing altitude due to chemical reactions and photodissociation in the stratosphere. By taking into account the $\mathrm{N}_{2} \mathrm{O}$ depletion during transport of air from the tropical troposphere to the Antarctic stratosphere, the secular increase in stratospheric $\mathrm{CH}_{4}$ can be detected from measured values.

\section{Acknowledgements}

We are grateful to the members of the 38-39th, 44-45th, 48-49th, and 53-54th Japanese Antarctic Research Expedition (JARE), who were integral in conducting the balloon-borne air sampling experiments at Syowa. The balloon experiments were supported by the National Institute of Polar Research (NIPR) under the Ministry of Education, Culture, Sports, Science and Technology (MEXT), Japan. We also thank Drs. Gabriele P. Stiller and Florian J. Haenel (Karlsruhe Institute of Technology, Germany) for providing the zonally averaged $\mathrm{SF}_{6}$ data of MIPAS/ENVISAT and their valuable comments on the $\mathrm{SF}_{6}$ age in Antarctica. This study was partly supported by the General Collaboration Projects No. 24-14 and Project Research KP-3 from NIPR and by the JSPS KAKENHI Grant No. 21310014.

Edited by: T. Hirooka

\section{References}

Andrews, A. E., K. A. Boering, B. C. Daube, S. C. Wofsy, M. Loewenstein, H. Jost, J. R. Podolske, C. R. Webster, R. L. Herman, D. C. Scott, G. J. Flesch, E. J. Moyer, J. W. Elkins, G. S. Dutton, D. F. Hurst, F. L. Moore, E. A. Ray, P. A. Romashkin, and S. E. Strahan, 2001: Mean ages of stratospheric air derived from in situ observations of $\mathrm{CO}_{2}, \mathrm{CH}_{4}$, and $\mathrm{N}_{2}$ O. J. Geophys. Res., 106, 32295-32314.

Aoki, S., T. Nakazawa, S. Murayama, and S. Kawaguchi, 1992: Measurements of atmospheric methane at the Japanese Ant- arctic Station, Syowa. Tellus B, 44, 273-281, doi:10.1034/ j.1600-0889.1992.t01-3-00005.x.

Aoki, S., T. Nakazawa, T. Machida, S. Sugawara, S. Morimoto, G. Hashida, T. Yamanouchi, K. Kawamura, and H. Honda, 2003: Carbon dioxide variations in the stratosphere over Japan, Scandinavia and Antarctica. Tellus B, 55, 178-186, doi:10.1034/j.1600-0889.2003.00059.x.

Bischof, W., R. Borchers, P. Fabian, and B. C. Krüeger, 1985: Increased concentration and vertical distribution of carbon dioxide in the stratosphere. Nature, 316, 708-710, doi: $10.1038 / 316708 \mathrm{a} 0$.

Dlugokencky, E. J., L. Bruhwiler, J. W. C. White, L. K. Emmons, P. C. Novelli, S. A. Montzka, K. A. Masarie, P. M. Lang, A. M. Crotwell, J. B. Miller, and L. V. Gatti, 2009: Observational constraints on recent increases in the atmospheric $\mathrm{CH}_{4}$ burden. Geophys. Res Lett., 36, L18803, doi:10.1029/2009 GL039780.

Dlugokencky, E. J., P. M. Lang, J. W. Mund, A. M. Crotwell, M. J. Crotwell, and K. W. Thoning, 2017: Atmospheric carbon dioxide dry air mole fractions from the NOAA ESRL carbon cycle cooperative global air sampling network, 1968-2016, Version: 2017-07-28 (Available online at ftp://aftp.cmdl. noaa.gov/data/trace_gases/co2/flask/surface/, accessed 31 July 2017).

Engel, A., T. Möbius, H. Bönisch, U. Schmidt, R. Heinz, I. Levin, E. Atlas, S. Aoki, T. Nakazawa, S. Sugawara, F. Moore, D. Hurst, J. Elkins, S. Schauffler, A. Andrews, and K. Boering, 2009: Age of stratospheric air unchanged within uncertainties over the past 30 years. Nature Geosci., 2, 28-31, doi: 10.1038/Ngeo388.

Engel, A., H. Bönisch, M. Ullrich, R. Sitals, O. Membrive, F. Danis, and C. Crevoisier, 2017: Mean age of stratospheric air derived from AirCore observations. Atmos. Chem. Phys., 17, 6825-6838, doi:10.5194/acp-17-6825-2017.

Fischer, H., C. Blom, H. Oelhaf, B. Carli, M. Carlotti, L. Delbouille, D. Ehhalt, J.-M. Flaud, I. Isaksen, M. López-Puertas, C. T. McElroy, and R. Zander, 2000: Envisat-MIPAS, an instrument for atmospheric chemistry climate research. Eupopean Space Agency-Report SP-1229, C. Readings and R. A. Harris, Eds. ESA Publications Division, ESTEC, the Netherlands.

Flury, T., D. L. Wu, and W. G. Read, 2013: Variability in the speed of the Brewer-Dobson circulation as observed by Aura/ MLS. Atmos. Chem. Phys., 13, 4563-4575.

Foucher, P. Y., A. Chédin, R. Armante, C. Boone, C. Crevoisier, and P. Bernath, 2011: Carbon dioxide atmospheric vertical profiles retrieved from space observation using ACE-FTS solar occultation instrument. Atmos. Chem. Phys., 11, 24552470, doi:10.5194/acp-11-2455-2011.

GLOBALVIEW- $\mathrm{CO}_{2}$ (2013), Cooperative Global Atmospheric Data Integration Project. 2013, updated annually. Multilaboratory compilation of synchronized and gap-filled atmospheric carbon dioxide records for the period 1979-2012 (obspack_co2_1_GLOBALVIEW-CO2_2013_v1.0.4_201312-23), Compiled by NOAA Global Monitoring Division: Boulder, Colorado, U.S.A. Data product accessed at http:// dx.doi.org/10.3334/OBSPACK/1002.

Haenel, F. J., G. P. Stiller, T. von Clarmann, B. Funke, E. Eckert, N. Glatthor, U. Grabowski, S. Kellmann, M. Kiefer, A. Linden, and T. Reddmann, 2015: Reassessment of MIPAS age of air trends and variability. Atmos. Chem. Phys., 15, 1316113176, doi:10.5194/acp-15-13161-2015.

Harnisch, J., W. Bischof, R. Borchers, P. Fabian, and M. Maiss, 1998: A stratospheric excess $\mathrm{CO}_{2}-$ due to tropical deep convection. Geophys. Res. Lett., 25, 63-66. doi:10.1029/ 97GL03398.

Holton, J. M., P. H. Haynes, M. E. Mclntyre, A. R. Douglass, R. B. Rood, and L. Pfister, 1995: Stratosphere-troposphere exchange. Rev. Geophys., 33, 403-439.

Honda, H., S. Aoki, T. Nakazawa, S. Morimoto, and N. Yajima, 1996: Cryogenic air sampling system for measurements of the concentrations of stratospheric trace gases and their 
isotopic ratios over Antarctica. J. Geomagn. Geoelectr., 48, 1145-1155, doi:10.5636/jgg.48.1145.

Linz, M., R. A. Plumb, E. P. Gerber, F. J. Haenel, G. Stiller, D. E. Kinnison, A. Ming, and J. L. Neu, 2017: The strength of the meridional overturning circulation of the stratosphere. Nature Geosci., 10, 663-667, doi:10.1038/ngeo3013.

Matsueda, H., T. Machida, Y. Sawa, and Y. Niwa, 2015: Longterm change of $\mathrm{CO}_{2}$ latitudinal distribution in the upper troposphere. Geophys. Res. Lett., 42, 2508-2514, doi:10.1002/ 2014GL062768.

Michelsen, H. A., G. L. Manney, M. R. Gunson, C. P. Rinsland, and R. Zander, 1998: Correlations of stratospherec abundances of $\mathrm{CH}_{4}$ and $\mathrm{N}_{2} \mathrm{O}$ derived from ATMOS measurements. Geophys. Res. Lett., 25, 2777-2780.

Morimoto, S., T. Nakazawa, S. Aoki, G. Hashida, and T. Yamanouchi, 2003: Concentration variation of the atmospheric $\mathrm{CO}_{2}$ observed at Syowa Station, Antarctica from 1984 to 2000. Tellus B, 55, 170-177, doi:10.1034/j.1600-0889.2003. 0147.x.

Morimoto, S., T. Yamanouchi, H. Honda, I. Iijima, T. Yoshida, S. Aoki, T. Nakazawa, S. Ishidoya, and S. Sugawara, 2009: A new compact cryogenic air sampler and its application in stratospheric greenhouse gas observation at Syowa Station, Antarctica. J. Atmos. Oceanic Technol., 26, 2182-2191, doi: 10.1175/2009JTECHA1283.1.

Nakazawa, T., T. Machida, S. Sugawara, S. Murayama, S. Morimoto, G. Hashida, H. Honda, and T. Itoh, 1995: Measurements of the stratospheric carbon dioxide concentration over Japan using a Balloon-borne cryogenic sampler. Geophys. Res. Lett., 22, 1229-1232, doi:10.1029/95GL01188.

Nakazawa, T., M. Ishizawa, K. Higuchi, and B. A. N. Trivett, 1997: Two curve fitting methods applied to $\mathrm{CO}_{2}$ flask data. Environmetrics, 8, 197-218.

Nakazawa, T., S. Aoki, K. Kawamura, T. Saeki, S. Sugawara, H. Honda, G. Hashida, S. Morimoto, N. Yoshida, S. Toyoda, Y. Makide, and T. Shirai, 2002: Variations of stratospheric trace gases measured using a balloon-borne cryogenic sampler. Adv. Space Res., 30, 1349-1357.

Reddmann, T., R. Ruhnke, and W. Kouker, 2001: Three-dimensional model simulations of $\mathrm{SF}_{6}$ with mesospheric chemistry. J. Geophys. Res., 106, 14525-14537.

Rigby, M., J. Mühle, B. R. Miller, R. G. Prinn, P. B. Krummel, L. P. Steele, P. J. Fraser, P. K. Salameh, C. M. Harth, R. F. Weiss, B. R. Greally, S. O'Doherty, P. G. Simmonds, M. K. Vollmer, S. Reimann, J. Kim, K.-R. Kim, H. J. Wang, J. G. J. Olivier, E. J. Dlugokencky, G. S. Dutton, B. D. Hall, and J. W. Elkins, 2010: History of atmospheric $\mathrm{SF}_{6}$ from 1973 to
2008. Atmos. Chem. Phys., 10, 10305-10320, doi:10.5194/ acp-10-10305-2010.

Rohs, S., C. Schiller, M. Riese, A. Engel, U. Schmidt, T. Wetter, I. Levin, T. Nakazawa, and S. Aoki, 2006: Long-term changes of methane and hydrogen in the stratosphere in the period 1978-2003 and their impact on the abundance of stratospheric water vapor. J. Geophys. Res., 111, D14315, doi: 10.1029/2005JD006877.

Rosenlof, K. H., 2002: Transport changes inferred from HALOE water and methane measurements. J. Meteor. Soc. Japan, 80, 831-848.

Schmidt, U., and A. Kheidim, 1991: In situ measurements of carbon dioxide in the winter Arctic vortex and at midlatitudes: An indicator of the age of stratospheric air. Geophys. Res. Lett., 18, 763-766, doi:10.1029/91GL00022.

Strunk, M., A. Engel, U. Schmidt, C. M. Volk, T. Wetter, I. Levin, and H. Glatzel-Mattheier, 2000: $\mathrm{CO}_{2}$ and $\mathrm{SF}_{6}$ as stratospheric age tracers: Consistency and the effect of mesospheric $\mathrm{SF}_{6}$ loss. Geophys. Res. Lett., 27, 341-344.

Sugawara, S., T. Nakazawa, Y. Shirakawa, K. Kawamura, and S. Aoki, 1997: Vertical profile of the carbon isotopic ratio of stratospheric methane over Japan. Geophys. Res. Lett., 24, 2989-2992, doi:10.1029/97GL03044.

Sugawara, S., S. Toyoda, S. Ishidoya, S. Morimoto, G. Hashida, S. Aoki, T. Nakazawa, T. Yamanouchi, and H. Honda, 2010: Stratospheric greenhouse gas observantion using a balloonborne cryogenic sampler at Syowa Station, Antarctica. Nankyoku Shiryô (Antarctic Record), 54, 410-425.

Sugawara, S., S. Ishidoya, S. Aoki, S. Morimoto, T. Nakazawa, S. Toyoda, Y. Inai, F. Hasebe, C. Ikeda, H. Honda, D. Goto, and F. A. Putri, 2017: Age and gravitational separation of the stratospheric air over Indonesia. Atmos. Chem. Phys. Discuss., in review, (Available online at https://doi.org/ 10.5194/acp-2017-583, accessed 24 June 2015).

Toyoda, S., N. Yoshida, T. Urabe, Y. Nakayama, T. Suzuki, K. Tsuji, K. Shibuya, S. Aoki, T. Nakazawa, S. Ishidoya, K. Ishijima, S. Sugawara, T. Machida, G. Hashida, S. Morimoto, and H. Honda, 2004: Temporal and latitudinal distributions of stratospheric $\mathrm{N}_{2} \mathrm{O}$ isotopomers. J. Geophys. Res., 109, D08308, doi:10.1029/2003JD004316.

Waugh, D. W., and T. M. Hall, 2002: Age of stratospheric air: Theory, observations, and models. Rev. Geophys., 40, 1010, doi:10.1029/2000RG000101.

Manuscript received 20 August 2017, accepted 2 November 2017 SOLA: https://www.jstage.jst.go.jp/browse/solal 